\title{
Sunflower meal concentrations in Massai grass silage
}

\author{
La harina de girasol en el ensilaje de hierba Massai
}

\author{
Máikal S. Borja, ${ }^{1 *}$ M.Sc, Ronaldo L. Oliveira, ${ }^{2}$ D.Sc, Luciano S. Lima, ${ }^{3}$ M.Sc, Adriana R. \\ Bagaldo, ${ }^{1}$ D.Sc, Gleidson GP. Carvalho, ${ }^{2}$, Cláudio VDM Ribeiro, ${ }^{2}$ Ph.D
}

\begin{abstract}
${ }^{1}$ Universidade Federal do Recôcavo da Bahia, Pós Graduação em Ciência Animal, Cruz da Almas, Brasil. ${ }^{2}$ Universidade Federal da Bahia, Escola de Medicina Veterinária e Zootecnia, Departamento de Produção Animal, Salvador, Brasil. ${ }^{3}$ Federal University of Bahia. *Correspondence: maikalborja@ hotmail.com.
\end{abstract}

Recibido: Febrero de 2011; Aceptado: Diciembre de 2011.

\begin{abstract}
Objetive. This experiment was conducted to evaluate the best sunflower meal concentration in Massai grass silage. Materials and methods. The treatments were composed of $0,8,16$, and $24 \%$ sunflower meal (natural matter basis) during ensiling of Massai grass, with four repetitions. Results. The regression equation showed that the inclusion of sunflower meal between $2.14 \%$ and $13.91 \%$ obtained a silage dry matter between 25 and 35\%, which are the values recommended for the production of high quality silage. The addition of sunflower meal showed a linear increase in crude protein, reaching $18 \%$ DM with the highest concentration of sunflower meal. The highest feed value index was obtained with the addition of $24 \%$ sunflower meal in the silage. The estimated total digestible nutrient of silage increased linearly with sunflower meal concentration. The silage pH values had a quadratic effect, reaching the lowest value (4.1) with $15 \%$ sunflower meal addition. Conclusions. Based on the chemical composition and forage quality, a concentration of $14 \%$ sunflower meal should be used for high-quality silage with good nutritional value..
\end{abstract}

Key words: Energy, fermentation, forage value index, ruminants, silage (Source:CAB).

\section{RESUMEN}

Objetivo. Este trabajo se llevó a cabo para determinar el porcentual adecuado de harina de girasol en ensilaje de hierba Massai. Materiales y métodos. La harina de girasol fue adicionada en $0,8,16$, y $24 \%$ durante el ensilaje de hierba Massai, con cuatro repeticiones por tratamiento. Resultados. La inclusión de la torta de girasol entre $2.14 \%$ y $13.91 \%$ resultó en porcentuales de materia seca entre 25 y $35 \%$, que son los valores recomendados para la producción de forraje de alta calidad. La adición de harina de girasol proporcionó un aumento lineal de proteína cruda, alcanzando el $18 \%$ de MS con la mayor concentración de harina de girasol. El más alto índice de alimentación se obtuvo con la adición de un $24 \%$ de harina de girasol. La concentración de harina de girasol también tuvo efecto lineal sobre el total de nutrientes digestibles del ensilado de hierba Massai, mientras el pH del ensilaje tuvo un comportamiento cuadrático, alcanzando el más bajo valor (4.1) con $15 \%$ de harina de girasol. Conclusiones. Por fin, este trabajo recomienda $14 \%$ de harina de girasol para obtener un ensilado de la Hierba Massai con alta calidad y bueno valor nutricional.

Palabras clave: Energía, ensilaje, fermentación, rumiantes, valor forrajero (Fuente:CAB). 


\section{INTRODUCTION}

Tropical forages present seasonal cycles, and for this reason are unable to meet the nutritional requirements of animals in the period of low forage production. Among the alternative forages, grass silage is an option, since it allows for the use of surplus fodder grown during the rainy season.

Among tropical forage potential for silage, a Massai grass (Panicum maximum cv. Massai) hybrid has been produced by Embrapa since 2001, with dry matter (DM) production of 15.6 t/ha/year. Its main features are a greater leaf/ stem ratio and a greater resistance to climatic influences than the other forages of the same genus. Thus, it has become an alternative forage for diversifying grazing and a potential green mass producer.

However, tropical forages, with a good nutritional value, have low percentages of DM and soluble carbohydrates; characteristics undesirable for ensiling. These are features that do not favour the production of silage, and requires the use of additives. These products are added to green mass, with the purpose of improving fermentation, digestibility and acceptability, plus promoting the nutritional value of the forage.

Absorbing additives are used to reduce nutrient loss caused by waste and environmental pollution, especially in forages low in DM. In this context, sunflower meal appears to be an alternative absorbent additive that can be used in the process of ensiling to promote the production of quality silage. Sunflower meal is a by-product of sunflower oil. It can be used in animal feed as a quality protein source.

The aim of this study was to determine the optimum concentration of sunflower meal in Massai grass at the time of ensiling, by evaluating chemical composition, fermentation characteristics, energy content of feed value and estimations of intake and digestibility.

\section{MATERIALS AND METHODS}

Study site. The experiment was conducted at the Experimental Farm of the School of Veterinary Medicine, Federal University of Bahia (UFBA), located in the municipality of São Gonçalo dos Campos (12²3'58.27'South, 38 $52^{\prime} 44.65^{\prime \prime}$ West).

After 40 days of regrowth, Massai grass was manually cut to $10 \mathrm{~cm}$ from the soil and crushed particle size of approximately $4 \mathrm{~cm}$ using a disintegrating machine. The treatments were a combination of Massai grass and different concentrations of sunflower meal. The 16 laboratory silos were made using $15 \mathrm{~L}$ buckets, covered with plastic film and sealed with tape. At the bottom of each silo was placed $1 \mathrm{~kg}$ of sand, separated from the forage by a porous mesh, so it was possible to measure the amount of effluent produced.

Treatments, silos and samples. The treatments were sunflower meal concentrations of $0,8,16$, and $24 \%$ in green herbage of Massai grass during ensiling, with four replicates. Samples of grass and sunflower meal were collected and stored for further analysis (Table 1). Silos were packed manually with the aid of wooden bars and sealed with plastic and tape, so as to preclude the entry of air. After 60 days, the experimental silos were opened and samples were collected from the centre of each laboratory silo.

Table 1. Chemical-bromatologic composition of contents used in the production of silage.

\begin{tabular}{lcc}
\hline \multicolumn{1}{c}{ Items } & \multicolumn{2}{c}{ Content (\%) } \\
& Massai Grass & Sunflower Meal \\
\hline Dry Matter (\%) & 21.28 & 93.28 \\
Crude Protein $^{1}$ & 5.40 & 27.38 \\
Mineral Matter $^{1}$ & 10.28 & 5.48 \\
Ether Extract $^{1}$ & 0.68 & 6.74 \\
Non-Fiber Carbohydrates $^{1}$ & 15.93 & 18.04 \\
Fiber Neutral Detergent $^{1}$ & 67.71 & 42.36 \\
Acid Detergent Fiber $^{1}$ & 48.62 & 26.94 \\
Hemicellulose $^{1}$ & 19.08 & 15.42 \\
Cellulose $^{1}$ & 38.19 & 8.57 \\
Lignin $^{1}$ & 10.43 & 6.85 \\
\hline
\end{tabular}

$1 \%$ of Dry Matter.

Samples were dried in an oven at $65^{\circ} \mathrm{C}$ for 72 hours, then ground into a $1 \mathrm{~mm}$ sieve for analysis of dry matter (DM), crude protein (CP), mineral matter (MM) fiber neutral detergent (NDF), acid detergent fiber (ADF), ether extract (EE), hemicellulose (HEM), cellulose (CEL) and lignin (LIG), according to methods described by Silva and Queiroz (1). The levels of nonfiber carbohydrates (NFC) were estimated based on Sniffen et al (2), where NFC $=100$ $(\mathrm{CP} \%+\mathrm{NDF} \%+\mathrm{EE} \%+\mathrm{MM} \%)$. The tests were performed at the Laboratory of Animal Nutrition, School of Veterinary Medicine at UFBA.

General Measurements. Measurements of ammonia nitrogen levels (NH3-N) were performed as described by Silva and Queiroz (1) and pH analysis was accomplished using a digital potentiometer, at the time of opening of the silos. 
Forage value index (FVI) was obtained through the following equations described by Crampton et al (3), dry matter intake DMI(\% of body weight) $=120 \%$ NDF of the forage (equation 1 ); digestible dry matter $\operatorname{DDM}(\%)=0.779 \times 88.9 \%$ ADF digestibility of forage (equation 2); forage value index $(F V I)=(x$ MSD MSI) $/ 1.29$ (equation 3 ), where DMI is dry matter intake and DDM is digestible dry matter.

Estimated total digestible nutrients (TDN) were made from the composition of each silage assessed according to the equations proposed by the NRC (4), which estimates levels of digestible crude protein (DCP), digestible fatty acids (DFA), fiber digestible neutral detergent free protein (NDFp), and non-fiber carbohydrate digestible (DNFC), as described below:

CPD to forage $\mathrm{CPx}=$ exponential $(-1.2 \times(\mathrm{PADI} / \mathrm{CP}))$;

CPD food concentrates $C P=x[1-(0.4 \times P A D I / C P)]$; such that protein $\mathrm{PADI}=$ acid detergent insoluble;

$D F A=(E E-1) \times 100 ;$

DNFC $=0.98 \times$ NFC FAP; where FAP = adjustment factor for physical processing, which in this case was considered worth FAP $=1.0$.

NDF $=0.75(N D F p-L) \times[1-(L / N D F p) 0.667]$ where $\mathrm{L}=$ Lignin.

To estimate the total digestible nutrients (TDN), according to the NRC (4), the equation used was: $T D N=D C P+2.25+A G D+N D F+D N F C-7$.

The data were analysed using analysis of variance and regression, assuming a significance level of $5 \%$, with the help of the statistical software package SISVAR 5.1.

Table 2. Chemical - Bromatologic composition of Massai grass ensilages with different levels of sunflower meal.

\begin{tabular}{|c|c|c|c|c|c|c|c|}
\hline \multirow[t]{2}{*}{${ }^{\mathbf{1}_{\text {Itens }}}$} & \multicolumn{4}{|c|}{$\begin{array}{c}\text { Levels of sunflower } \\
\text { meal }(\%)\end{array}$} & \multirow{2}{*}{$\begin{array}{l}\text { Regression } \\
\text { Equation }\end{array}$} & \multirow[t]{2}{*}{ CV } & \multirow[t]{2}{*}{$\mathbf{R}^{2}$} \\
\hline & 0.0 & 8.0 & 16.0 & 24.0 & & & \\
\hline DM (\%) & 23.9 & 27.9 & 38.7 & 43.0 & $\hat{Y}=23.2+0.85 x$ & 7.12 & 96.3 \\
\hline $\mathrm{CP}$ & 7.3 & 11.6 & 14.9 & 17.9 & $\hat{Y}=7.6+0.4 x$ & 9.22 & 99.4 \\
\hline EE & 1.6 & 2.8 & 4.2 & 4.7 & $\hat{Y}=2.1+0.098 x$ & 13.6 & 51.2 \\
\hline NDF & 65.3 & 58.9 & 56.0 & 52.2 & $\hat{Y}=64.5-0.53 x$ & 2.40 & 97.2 \\
\hline ADF & 44.5 & 42.5 & 37.3 & 35.5 & $\hat{Y}=44.7-0.4 x$ & 4.45 & 95.9 \\
\hline Cellulose & 32.4 & 28.8 & 28.0 & 26.5 & $\hat{Y}=31.7-0.23 x$ & 4.17 & 91.8 \\
\hline Hemicellulose & 20.8 & 16.5 & 18.7 & 16.6 & $\hat{Y}=19.7-0.13 x$ & 6.37 & 42.1 \\
\hline Lignin & 12.1 & 13.6 & 9.3 & 9.1 & $\hat{Y}=11.03$ & - & - \\
\hline NFC & 13.8 & 13.1 & 18.8 & 17.6 & $\hat{Y}=13.8+0.2 x$ & 12.0 & 62.1 \\
\hline
\end{tabular}

$1_{\mathrm{MD}}$ : Dry Matter, CP: Crude protein, EE: Ether Extract, NDF: Neutral Detergent Fiber, ADF Acid Detergent Fiber, NFC: Non-Fiber Carbohydrates.

\section{RESULTS}

The inclusion of sunflower meal promoted linear increase $(p<0.05)$ in dry matter $(D M)$, crude protein $(\mathrm{CP})$, ether extract (EE) and non-fiber carbohydrates (NFC) levels of massai grass silage (Table 2). The levels of neutral and acid detergent fiber (NDF and ADF), cellulose and hemicellulose decreased linearly $(p<0.05)$. The sunflower meal did not influence the levels of lignin in massai grass silage.
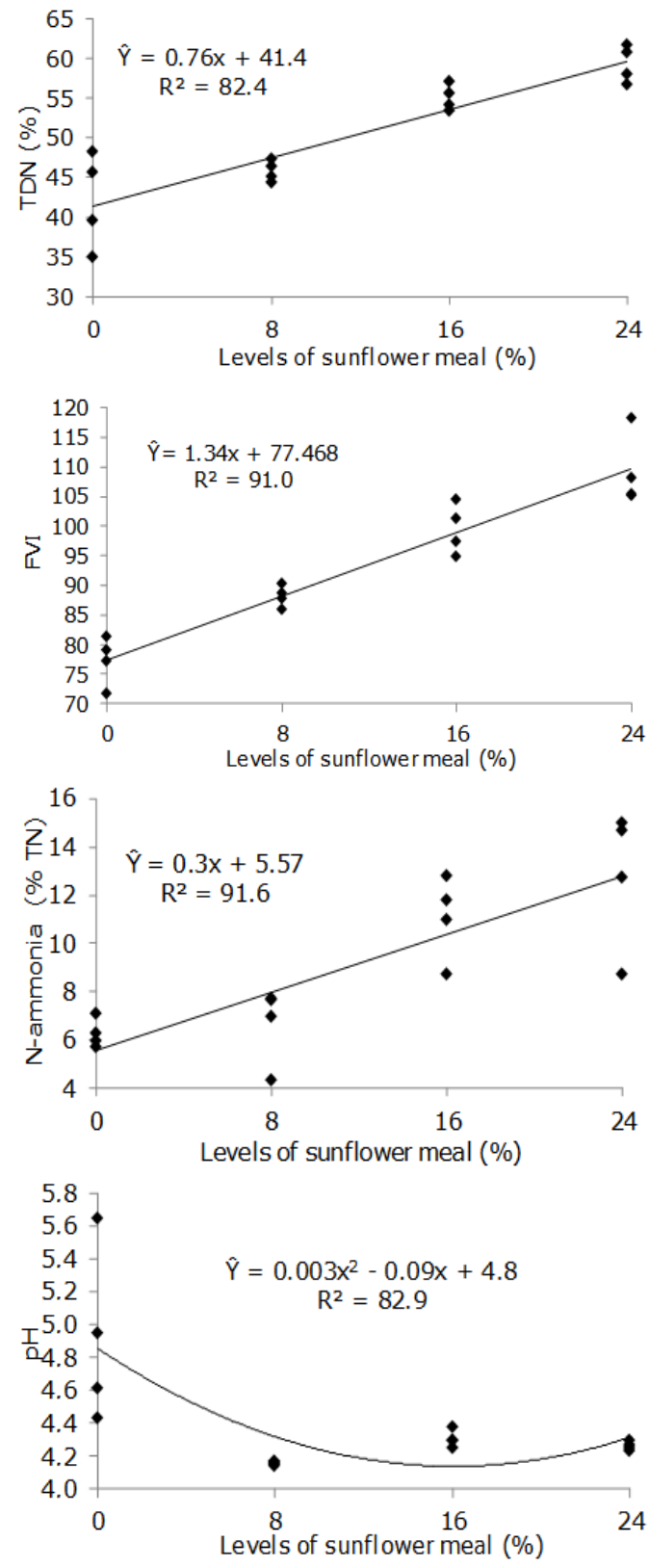

Figure 1. a) Estimates of TDN, b) Forage Value Index (FVI), c) $\mathrm{N}$-ammonia and d) $\mathrm{pH}$ of silages of Massai grass with levels of sunflower meal. 
O TDN and FVI of massai grass silage were influenced to an increasing linear by the inclusion of sunflower meal (Figure $1 \mathrm{a}$ and $1 \mathrm{~b}$ ). In the evaluatuion of the quality parameters of massai grass silage, N-amoniacal increased with the inclusion of sunflower meal (Figure 1c). while the $\mathrm{pH}$ of massai grass silage presented a quadratic positive with the inclusion of sunflower meal. With the addition os $15 \%$ of sunflower meal in the massai grass silage, the equation we can estimate the lower $\mathrm{pH}$ silage wich is 4.1.

\section{DISCUSSION}

DM concentrations observed in this study with sunflower meal concentrations of $2.14 \%$ to $13.91 \%$ in NM silage were within the range established by Ribeiro et al (5), who recommended that the DM of ensiled material be around 25 to $35 \%$ to ensure the production of good quality silage. Therefore, the inclusion of one percentage point of sunflower meal in Massai grass ensilage allowed for an increase of $0.83 \%$ in DM content (Table 2), which may be explained by the DM content of sunflower meal (Table 1 ). These results are consistent with those observed by Carvalho et al (6), who worked with by-products, and observed significant increases in DM digestibility of elephant grass with cocoa meal. The significant linear reduction $(p<0.05)$ in NDF and ADF, according to the concentrations of sunflower meal in silage (Table 2), was probably due to the lower levels of NDF present in the additive (Table 1 ). Thus, each percentage point of meal concentrate led to a decrease of $0.53 \%$ in NDF. With the replacement of grass by sunflower meal, the effect of reducing fiber levels was observed. This result corroborates those found by Ribeiro et al (7), where the inclusion of wheat bran in Tanzania grass silage lowered the observed levels of NDF in the silages.

Sunflower meal concentrations linearly increased $\mathrm{CP}$ content (Table 2), allowing CP values of sunflower meal-supplemented silage to increase more than $8 \%$. These values are considered by Carvalho et al (8) as the minimum level required to not limit fiber fermentation by ruminal microbes. Thus, with $16 \%$ inclusion of sunflower meal, Massai grass silage received approximately $15 \%$ crude protein, higher than most other grass silages. Ferreira et al (9) worked with pineapple products in elephant grass silage, and observed maximum values of about $6 \%$ CP. Carvalho et al (10) used shell coffee in elephant grass silage, and found maximum values of $9 \% \mathrm{CP}$.
Fractions of cellulose, hemicellulose and lignin decreased $(p<0.05)$ with the inclusion of sunflower meal, demonstrating that addition of this additive made a more digestible silage, estimated by the characteristic index of nutritive value (IVF). There was a high amount of lignocellulose and a higher proportion of mobile content; therefore, a larger fraction of carbohydrates (NFC), which are readily digestible. With the increase in CNF, the decrease in lignin content possibly provided greater digestibility. This fact can be explained by the reduction of lignin that allows for better use of fiber by microorganisms. The results are in agreement with Rodrigues et al (11), who observed an increase in NFC with the inclusion of citrus pulp in elephant grass silage, which was attributable to the higher level of NFC in citrus pulp.

The EE showed a positive linear $(p<0.05)$ change with the addition of sunflower meal in Massai grass silage (Table 2). This behaviour could be explained by the high content of this fraction in sunflower meal (Table 1). Thus, the EE present in sunflower meal raised the energy level of grass silage, improving forage quality. The results are similar to those of Carvalho et al (6), who, when using cocoa meal on elephant grass silage, observed increased levels of EE silage, which may be explained by the similarity of the levels of EE present in products.

The estimated values for TDN of silages increased $(p<0.05)$ linearly with sunflower meal concentration (Figure 1a). Increased TDN could be attributed to high levels of $\mathrm{CP}$ and NFC in sunflower meal (Table 1). The estimate of TDN of silages, obtained by the equation described by Weiss et al (12) and adapted by the NRC (4), consider the digestible CP, digestible EE, digestible NDF and digestible NFC. Thus, increased levels of TDN in silages can promote better utilisation of forage by ruminants, thereby providing greater energy intake, and therefore, better performance of these animals.

The lower IVF found (77.32) was for silage without the addition of sunflower meal, classified as grade 3 forage based on the work by Teixeira and Andrade (3). The same degree fits elephant grass pasture, a forage widely used in ruminant feed. A higher IVF (Figure 1b) was obtained with the addition of $24 \%$ of sunflower meal in silage (109.27), which was lower than the value found by Ribeiro et al (7) of 122.82 with the addition of $24 \%$ wheat bran to grass.

The significant increase in IVF with the addition of sunflower meal could be explained by the low 
NDF and ADF of this additive. With the addition of the meal, NDF and ADF in silage was reduced (Table 2) and these fractions had an inverse relationship to IVF. Another factor that must also be taken into account is that the addition of sunflower meal promoted an increase in soluble carbohydrates, which is crucial for the rapid decrease in $\mathrm{pH}$ in the ensiled material and therefore promotes preservation of the silage.

The $\mathrm{pH}$ values varied in a quadratic fashion, depending on the concentration of sunflower meal $(p<0.05)$, with an estimated minimum value of 4.1 for the standard of $15 \%$ sunflower meal. Among these treatments, Massai grass silages with 8, 16 and $24 \%$ sunflower meal had $\mathrm{pH}$ within the range considered optimal (3.8 to 4.2) for adequate fermentation, according to Jobim et al (13).

High $\mathrm{pH}$ is indicative of increased production of acetic and butyric acids, characteristic of the processes of fermentation reactions, as shown by Van Soest (14). It seems that the higher levels of carbohydrates observed in sunflower meal (Table 1) contributed to the rapid decrease in $\mathrm{pH}$, which favoured the production of lactic acid.

The concentration of NH3-N increased linearly $(p<0.05)$, depending on sunflower meal concentration (Figure 1c). The increase in CP content with the inclusion of sunflower meal might have increased proteolysis in the first phase of the fermentation process. During this phase, the $\mathrm{pH}$ was still high, favoring the growth of proteolytic bacteria (14). But even the $14 \%$ level of inclusion of sunflower meal, silage presented values that are accepted in good quality silage, around a maximum of $10 \%$ NH3-N as proposed by Jobim et al (13).

In conclusion, based on the chemical composition and indicators of forage quality, a $14 \%$ concentrate of sunflower meal provided appropriate values for the improvement of Massai grass silage quality, with good nutritional value.

\section{REFERENCES}

1. Silva DJ, Queiroz AC. Análise de alimentos: métodos químicos e biológicos. 3th ed. Viçosa, MG: Editora UFV; 2002.

2. Sniffen CJ, O'Connor JD, Van Soest PJ, Fox DG, Russell JB. A net carbohydrate and protein system for evaluating cattle diets. II. Carbohydrate and protein availability. J Anim Sci 1992; 70:3562-3577.

3. Crampton EW, Donefer E, Lloydn LE. A nutritive value index for forages. J Dairy Sci 1960; 19:538-544.

4. National Research Council. Nutrient requeriments of dairy cattle. 70 ed. Washinton: NRC; 2001.

5. Ribeiro JL, Nussio LG, Mourão GB, Queiroz OCM, Santos MC, Schmidt P. Efeitos de absorventes de umidade e de aditivos químicos e microbianos sobre o valor nutritivo, o perfil fermentativo e as perdas em silagens de capim-marandu. Rev Bras Zootecn 2009; 38:230-239.
6. Carvalho GGP, Garcia R, Pires AJV, Pereira OGP, Azevêdo AG, Carvalho BMA, Cavali. J. Valor nutritivo de silagens de capimelefante emurchecido ou com adição de farelo de cacau. Rev Bras Zootecn 2007; 36:1495-1501.

7. Ribeiro RDX, Oliveira RL, Bagaldo $A R$, Faria EFS, Garcez Neto AF, Silva TM, Borja MS, Cardoso Neto BM. Capim-tanzânia ensilado com níveis de farelo de trigo. Rev Bras Saúde Prod An 2008; 9:631-640.

8. Carvalho GGP, Pires AJV, Veloso CM, Magalhães $A F$, Freire $M A L$, Silva $F F$, Silva RR, Carvalho BMA. Valor nutritivo do bagaço de cana-de-açucar amonizado com quatro doses de uréia. Pesq agropec bras 2006; 41:125-132.

9. Ferreira $\mathrm{ACH}$, Neiva JNM, Rodriguez NM, Campos WE, Borges I. Avaliação nutricional do subproduto da agroindústria de abacaxi como aditivo de silagem de capim-elefante. Rev Bras Zootecn 2009; 38:223-229. 
10. Carvalho GGP, Garcia R, Pires AJV, Azevêdo AG, Fernades EP, Pereira OG. Valor nutritivo e características fermentativas de silagens de capim-elefante com adição de casca de café. Rev Bras Zootecn 2007; 36:1875-1881.

11. Rodrigues PHM, Borgatti LMO, Gomes RW, Passini R, Meyer PM. Efeito da adição de níveis crescentes de polpa cítrica sobre a qualidade fermentativa e o valor nutritivo da silagem de capim-elefante. Rev Bras Zootecn 2005; 34:1138-1145.
13. Jobim CC, Nussio LG, Reis RA, Schmidt P. Avanços metodológicos na avaliação da qualidade de forragem conservada. Rev Bras Zootecn 2007; (supl):101-119.

12. Weiss WP. Predicting energy values of feed. In. Symposium: prevailing concepts in energy utilization by ruminants. J Dairy Sci 1993; 76:1802-1811.

14. Van Soest PJ. Nutritional ecology of the ruminant. 2nd ed. Ithaca: Cornell University Press; 1994. 